\title{
Researching vernacular Judaism Reflections on theory and method
}

\author{
Ruth Illman
}

$\mathbf{y}$

VERTAISARVIOITU

KOLLEGIALT GRANSKAD

PEER-REVIEWED

www.tsv.fi/tunnus

DOI: https://doi.org/10.30752/nj.77287

\begin{abstract}
AвSTRACt - This article presents the ethnographically driven multi-method research perspective of vernacular religion and analyses its potential to contribute to the theoretical advancement of Jewish studies. The ongoing discussion on religion and change within the study of religions in general and Jewish studies in particular is outlined and structured around three 'turns' identified in the research on vernacular religiosity. To exemplify these theoretical and methodological considerations, a recently initiated research project focusing on vernacular Judaism in Finland is presented. This project seeks to examine central ideas of boundaries as they are negotiated and interpreted among Finnish Jewry, to compare the emerging patterns with Nordic counterparts and thus contribute to a more nuanced perception of Jewish identities in these contexts. The article concludes with a discussion on the advances of such an approach, pointing to the relative novelty of research into vernacular religion within Jewish studies and the exceptionality of the Finnish Jewish context.
\end{abstract}

\section{Introduction: boundaries}

The boundaries of religious identities are in constant commotion worldwide, today perhaps more so than ever before. Several significant boundaries, previously perceived as manifest markers of Jewish belonging, are currently being challenged and changed as static conceptions of identity, based on fixed dogmas, institutional belonging and family lineage, give way to more flexible apprehensions of Jewish identity (Aronson et al. 2018). Research on religion and change in contemporary Western societies stresses that increasing mobility, urbanisation and secularisation form the basis of several 'new normals' in defining ethnic and religious identities (Woodhead 20r6). Thus, many previous analytic models within the research on religion no longer hold and new, more complex, adaptive and polygonal ones are needed, which are sensitive to the dynamics of multi-ethnic and multi-religious societies.
This article seeks to outline one possible path leading in that direction, tying in to recent developments within research on vernacular religion (Bowman and Valk 20I2; Illman 2018; Tweed 2015) and on identity and change in Jewish communities worldwide (Huss 2007; Ochs 2007; Summit 2016; Illman 2018). This starting point has informed a recently initiated research project investigating how Jews today negotiate their place within the religious and secular landscape of Finland. In order to shed light on how Finnish Jews as individuals and as a community find ways of 'being and doing Jewish' that feel historically embedded and religiously meaningful but simultaneously meet their personal needs and correspond to the secular lifestyle of their contemporary surroundings, the project develops a theoretical and methodological approach modelled on recent research pertaining to vernacular religion. This article seeks to demonstrate how 
this analytical framework can illuminate the research field in a novel way, clarifying how Jewish identifications are negotiated in Finland today and mapping out their significant boundaries.

\section{Vernacular religion}

Vernacular religion is defined as 'religion as it is lived: as human beings encounter, understand, interpret, and practice it' (Primiano I995: 44). This research approach presents a comprehensive view of religiosity which encompasses private and public, historical and cultural context, belief and practice, materiality, embodiment, social class and power, interweaving the different aspects into a broad image of religious subjectivities (Bowman and Valk 2012: 5). Developed as an analytic tool primarily within contemporary folklore and cultural studies it is today also widely applied within religious studies but has so far been applied to Jewish topics only scantily.

\section{Vernacular varieties}

Leonard Primiano developed the concept of vernacular religion as a tool for researching religion as a part of everyday life in a theoretically and methodologically systematic way, moving beyond the problematic opposition between 'official' and 'folk' religion (Primiano I 995: 52). In his view, much of the research on religion, explicitly or implicitly, starts from a dichotomous pre-understanding that portrays 'folk' as inferior to 'official', equating the former with 'distorted', 'popular' (in a negative sense) and 'superficial' and in parallel implying the existence of a category of 'pure', 'undistorted' and 'authentic' religion untainted by everyday lives, practices and human life in general (Bowman 2014: I02; Howard 201 I: 6). In contrast, vernacular religious research aims to study religion in everyday life without the pejorative burden implied in approaches to religion that regard the object of study religion - as a clear-cut, separate phenomenon (Bowman 2014: I02; Primiano 2012: 383). The vernacular approach pinpoints the problems involved in studying religion on the basis of a set of dichotomies and demonstrates why the juxtaposing of different forms of religious knowledge is unable to render ethnographic accounts meaningful or to illuminate contemporary religiosity: 'Vernacular religious theory understands religion as the continuous art of individual interpretation and negotiation of any number of influential sources' (Primiano 201 2: 384 ).

In contemporary scholarship, religious identifications and worldviews are increasingly approached as fluid, complex and rich in nuance rather than straightforward monoliths with stable durance (Bauman 2000; Taira 2006). There are several reasons behind this development. Not only has the binary differentiation between the official and popular or personal crumbled in contemporary, ethnographically driven research on religion - so too has the idea of religious and secular as mutually exclusive categories (Nynäs et al. 201 5: 219-20). The diversified process through which humans formulate their religious belongings and identifications often include incitements from various religious traditions and secular sources such as popular culture. This development appears paradoxical only against the background of a narrow, theoretical apprehension of religion as a downright intellectual search for plausible claims to truth (Poveda 20I7: I5-I6). Inspired by vernacular religious approaches, a growing number of studies investigate how theologically unsystematic life-views are formed through everyday religious lives and practices - and how these relate to institutional religion (Hovi 201 4: 80). In so doing, 
it is important to maintain the dialectic between institutional and everyday practice, the official and personal, while leaving the binary perspective behind (Howard 20II: 5-6).

Within research on religion, several corresponding terms are used in parallel. The notion of lived religion is widely used within empirical research on religion (McGuire 2008). Also, the term everyday religion has been suggested for research that focuses on experiences of religion described by individuals who are not religious professionals. This implies a sociological focus on religious activities that take form outside organised, institutional practices and on the many ways in which religion feeds into personal life-narratives (Ammerman 2007: 5-6). ${ }^{1}$

However, the vernacular-religion approach seems to cover the different aspects of research into everyday experiences and practices related to religion in the most comprehensive way, maintaining the dynamic link between individual experiences, preferences and perspectives on the one hand and larger contexts - formal as well as informal - on the other. Religious identifications and belongings are never negotiated in isolation. Therefore, vernacular views weave together the personally experienced with the historically organised and theologised. The need to find an inclusive perspective integrating both private and public, internal and external, personal and shared, expressed and experienced, motivates a further exploration of the vernacular approach, as studies pertaining to this tradition often focus more precisely on this dynamic dialogue than the more general research on lived or everyday religion. As

1 The relationship between these interrelated terms has been discussed by, for example, Leonard Primiano (2012) and Tuija Hovi (20I4).
Robert Howard contends, vernacular religion is "not merely "lived religion", it is a social entity made authoritative by everyday believers' repeated choices to connect' (Howard 2OII: 7).

\section{Flexibility and fluidity, roots and resources}

Flexibility, fluidity and change become keywords in vernacular religious research, focusing on the dialogue between self-reflexivity and external conditions such as physical and mental dispositions, the environment, family, political and economic conditions, education, media and so on. Paying attention to local detail is vital in this line of research (Bowman and Valk 20I2: 5, I6; Howard 20II: 5). Through speech, music and song, dance, ritual and drama as well as cuisine, dress and routines, performed religion offers insights into the versatile world of vernacular religion (Bowman and Valk 201 2: 7-8; Primiano 20I2: 385). Such expressions always bear personal imprints: 'There is always some passive accommodation, some intriguing survival, some active creation, some dissenting impulse, some reflection and lived experience that influences how [...] individuals direct their religious lives' (Primiano r 995: 46).

Primiano highlights three central concepts: ambiguity, power and creativity. As a strategy for handling ambiguity, the vernacular approach clarifies how various dimensions of belief and practice can be meaningfully integrated. The individual learns and adopts, accepts and rejects, changes or denies, values or devalues the religious elements provided by their surroundings. Through this process, both ambiguity and power as aspects of vernacular religion are at play. Concerning power, vernacular religion carries the potential both to legitimise existing hegemonies and to offer resistance against cultural and social forms of power - sometimes subtle, sometimes 
manifest. Creativity, finally, is an especially significant aspect of vernacular religion as it is often associated with expressive practices (Primiano 2012: 387-8). Human religiosity always includes a measure of artistry, innovation and adaptation. Hence, the vernacular approach is aptly suited for studying creative forms of everyday religiosity expressed in culture and customs (Primiano I 995: 43).

In conclusion, vernacular religion provides an analytic outlook that is, so to say, both 'bottom-up' and 'top-down' at the same time. It emphasises the continuous dialogue between personal narratives and socio-religious structures and maintains this dialectic throughout the research process. Hence, it needs to be acknowledged that vernacular Judaism, also among Finnish Jewry as the special focus of this article, is far from monolithic. It is a colourful and changing notion formed by an abundance of trivial and crucial choices relating to everyday life. Such choices are not made solely on religious or ethical grounds: they are also driven by economic and social circumstances, habits and chance. For a Jew in Finland, choices are often scarce: there is just one community, kosher food is scant and often expensive, potential partners may be hard to find within the small and tight-knit community (Lundgren 2006). It is out of such mundane but monumental elements that vernacular Judaism is built.

\section{The three turns}

Scholarly discussions of religion and change are often grand and general and thus too vague to render concrete ethnographic case studies and local data meaningful. Hence, it is important to tie the overarching arguments highlighted by the vernacular religion framework to more specific lines of argument and processes visible in contextually grounded data sets. Therefore, this article suggests that the framework of vernacular religion can be crystallised in three so-called 'turns' relevant for the research on contemporary vernacular Judaism: the 'reflexive turn', the 'turn within' and the 'turn to tradition'.

The 'reflexive turn' arises as a key explanation for contemporary religious change, expressed in an increasing emphasis on self-determination and fluidity in religious orientation. ${ }^{2}$ All over the Western world, institutional religions and traditional forms of religion seem to be 'experiencing a significant decline in power, popularity and prestige'. The interest in religiosity and existential dimensions of human life, however, is far from diminishing. Hence, secularism is challenged by novel, multi-layered outlooks often denoted 'post-secular', 'post-rationalist' or 'post-Enlightenment', including central features such as an emphasis on pluralism, the permeable line between the religious and the secular, connectivity and change (Illman 2017: 246-7). Commodification and consumption as well as popular cultural resources and digital communication also strongly influence contemporary religious landscapes in the West. In this context, many researchers attach importance to the growing privatisation of the religious field, outlining a 'sacralisation of subjectivities' in the Western world (Keysar 20I4: I60-I). The focus on radical religious individualism and 'self-authority' is, however, also paralleled by an emphasis on the importance of community and shared visions as well as social, ethnic, gendered and economic restraints that together form the context in which religious choices are made and positions defined (Altglas 20 I4: 327-9).

2 Fluidity as an aspect of contemporary religiosity can be meaningfully related to the sociological notion of liquid modernity, coined by Zygmunt Bauman (2000) and its development into a notion of liquid religion by Teemu Taira (2006). 
The second argument arising from previous research concerns the growing importance attached to emotions and embodiment as aspects of the religious engagement. Ole Riis and Linda Woodhead (2010: 3-4) stress that for a long time, emotional, bodily and relational factors were dismissed as overtly subjective and unscientific areas of inquiry within the study of religions. Today, however, as an 'unprecedented explosion of emotionality'seems to influence late modern individuals, societies and communities, growing scholarly attention is directed towards inclusive and non-binary investigations of religious emotion (ibid. I 84). Especially within the study of religion and music, a 'turn within' is highlighted, where growing attention is attached to bodily experiences, sensations and states of consciousness (Wijnia 20I6: 43). Expressive forms of religious engagement seem to have the ability to move and guide the imagination, thus creating novel and open spaces for meaning. Therefore, researchers are increasingly aware of the 'noncognitive dimensions of agency' and their significance for understanding contemporary religious identifications and positions (Partridge 2014: I, 37).

Finally, the third dimension focuses on a 'turn to tradition'. This innovative and embodied engagement with practices experienced as traditional results in a search for religious expressions and customs that are increasingly unfettered by traditional institutional divisions, adding to the flexibility and fluidity of contemporary religious identities (Kaplan 2007: I74). This overarching 'postdenominational' trend has been discussed globally across religious traditions, but has also been highlighted in relation to Judaism, in the United States (e.g. Cohen 20r 6; Kaplan 2007; Summit 2000, 2016; Wood 2016) as well as in Europe (Borts 2014: 289-90; Kahn-Harris and Gidley 2010: I02; Pinto 2008: 30-I; Poveda 2017). When attention is turned towards the subjective rather than the boundaries of historical institutions, the previously incommensurable ways of 'being' and 'doing' Jewish appear in a new light. As new generations of Jews explore their religious and cultural heritage, Ruth Ellen Gruber (2002: I86) argues, they feel free to 'emphatically reject metaphoric overtones and claim fulfilment simply in the music itself'. Hence, it is possible to leave behind the theological and doctrinal 'baggage' of practices originating in Jewish milieus far removed in time and ideology from the contexts in which they are

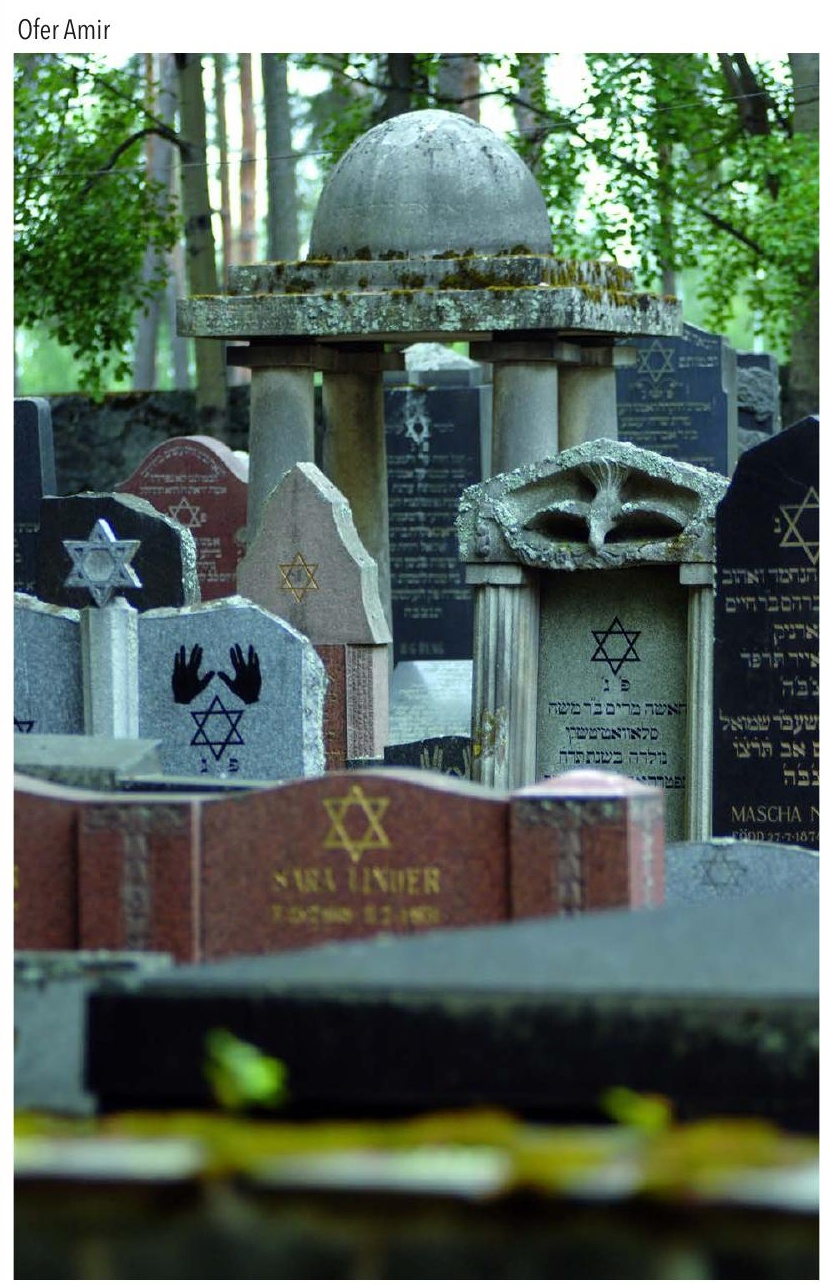

Gravestones at the Jewish cemetery in Helsinki. In earlier times, the stones were engraved in Hebrew. Later on Yiddish was also used and today also Swedish and Finnish. 
currently explored; that is, using the tradition as a source of inspiration, but not something to be bound by (Illman 201 8: xvi).

In the following, this three-fold argument will be examined in greater detail. However, it is important to note that these turns need to be addressed as incoherent, indeterminate and intertwined processes, and should not be understood as necessary developmental schemes pertaining to given regularities and laws. Rather, they offer a conceptual framework by which the otherwise fairly indeterminate theoretical trajectory offered by the vernacular perspective can be plotted.

\section{The reflexive turn}

Many researchers of religion today stress the fact that institutional religions and traditional forms of practice seem to be 'experiencing a significant decline in power, popularity and prestige' (Partridge 2014: 6) in the Western world, particularly in Europe. Nevertheless, traditional theories of secularisation foreseeing the imminent decline and subsequent death of religion at the threshold of modernity, characterised by a rapid progress of rationality, seem equally unsuccessful in their attempt to capture the essence of contemporary religious change. Instead, secular Westerners seem 'haunted by the possibility of an enchanted world' (ibid.). As a response to this paradox, several terms have lately entered the scholarly discussions of religion, such as 'post-secular' or 'late modern' (see e.g. Giordan and Pace 20r 2; Nynäs et al. 201 5). In the following, some relevant trends within this spectrum of change are analysed in greater detail.

One of the important contexts forming the changing religious landscape of today is the rapidly increasing pluralism of Western

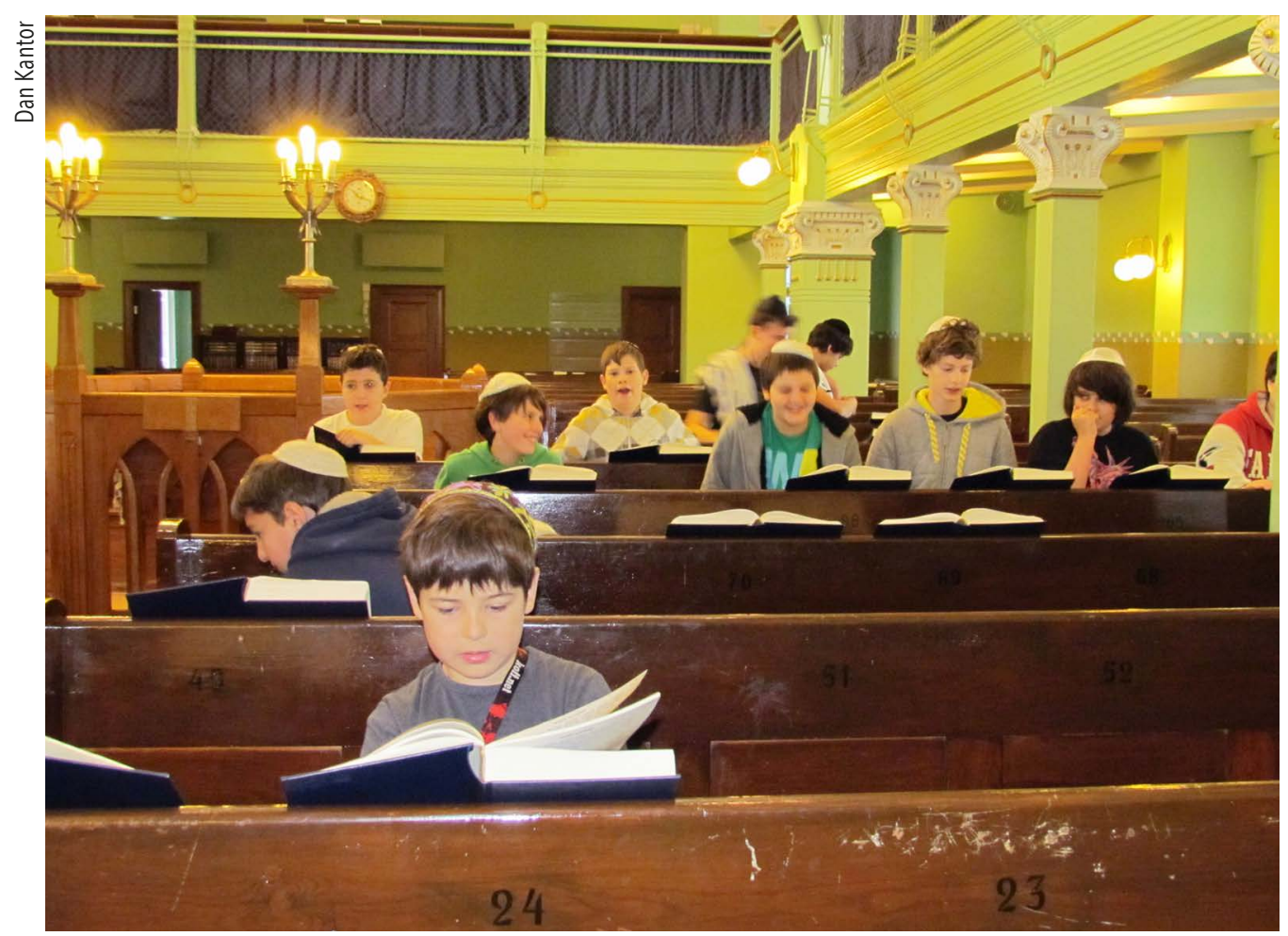

Pupils at the Jewish school in Helsinki taking part in the synagogue service. 
societies, in which a shared sense of religious identity, values and practices is disappearing (Giordan and Pace 2015: 3-4). In this situation of increased fluidity and fragmentation, individual and embodied forms of worship, strongly connected to experience-based and emotional dimensions of religion, seem to gain ground. Institutionally bound, intellectually grounded religious forms and formal authority, for their part, seem to become less persuasive (Nynäs et al. 201 5: 17-22). Ole Riis and Linda Woodhead (2010: I82) call this tendency a 'rejection of fixed forms of religious life'. The logic of the market and consumption also becomes increasingly relevant within the sphere of religion. Influences from popular culture, social media and digital worlds play prominent parts in shaping the religious landscape (Poveda 2017: I5-I6; Riis and Woodhead 2010: I73-4).

Many studies have drawn attention to the growing individualism characterising contemporary religious identifications, outlining a reflexive turn, a 'trend of privatisation' or a 'sacralisation of subjectivities' in the Western world (Riis and Woodhead 2010: I74-6). Influenced by such ways of thinking, presentday individuals seem to value free choice and eclecticism in matters of faith to a higher degree than before, rather than simply following in the footsteps of one's parents and adopting the religious outlook of the social and cultural milieu one has grown up in (Keysar 20I4: I60-I). Hence, Dana Kaplan notes that progressive Jews often embrace 'the popular belief in the sovereign self', focusing on their own religious feelings and personal understandings in forming their Jewish lives (Kaplan 2007: I69).

Within the sociology of religion, one of the established concepts describing this trend is bricolage, which denotes the creation of a conceptual framework or worldview on the basis of various influences (Riis and Woodhead 2010: 177, I84). ${ }^{3}$ A central assumption is that religious institutions today lose their influence over individual believers owing to the growing privatisation of religion. As a consequence, individuals can elaborate more freely in building their outlooks on life, exploring a vast range of available religious and cultural resources (Obadia 20I6). Bricolage can be used to describe an internal process of exploring 'exotic' aspects of the tradition one has grown up in, or an interreligious quest to combine religious and secular perspectives and practices into a personal, tailor-made worldview (Altglas 20 4: $5^{-6}$, I 2). It can be regarded as an innovative individual practice of breaking boundaries and the bricoleur as a playful explorer in a world of nearly unrestrained choices, driven by the neoliberal logics of consumerist culture (Illman 201 8: 6-7).

Véronique Altglas critically claims that the notion of bricolage 'largely overestimates its eclecticism, takes for granted the availability of religious resources, and misunderstands religious individualism' (Altglas 20I4: 5-6). As a result, the social and cultural frames that condition a person's possibilities to tailor their worldview as well as the power relations and hierarchies that define and delimit such processes are omitted. The focus on radical individualism and 'self-authority' neglects the fact that cohesion and collective aspects are part even of the most innovative bricoleur's

3 In the Merriam-Webster Dictionary 'bricolage' is defined as 'the construction or creation of a work from a diverse range of things that happen to be available'. Claude Lévi-Strauss introduced the term for anthropological research, using it to denote conceptual frameworks and worldviews creatively formed on the basis of various available influences (Merriam-Webster Dictionary online). 
worldview (Obadia 2016: 105-7). Social, ethnic, gendered and economic restraints form the context in which religious choices are made, establishing the process of bricolage along a structured scheme that augments the 'imperative to make choices - however constrained' (Riis and Woodhead 2010: I75). Thus, it seems as if personal subjectivity, choice and freedom are easily attributed too decisive a role when mapping contemporary religious and existential positions (Altglas 2OI 4: 326-3I).

\section{The turn within}

As noted above, a turn within has also been described in recent research, pointing to the growing attention attached to bodily experiences, sensations and states of consciousness that is attracting the interest of researchers of religion today (Wijnia 20r6: 43). A conceptual framework for analysing religious emotion, starting from an inclusive understanding of emotions as personal as well as relational, biological, social and cultural, has been proposed by Ole Riis and Linda Woodhead (2010). They portray emotions as formed through the interplay between individuals, social structures and symbols. This means that emotions are shaped by the individual's subjective world, but also by interpersonal relations, cultural symbols and material settings. When emotions are regarded as 'belong[ing] to the situation as a whole' (ibid. 6-7), it is possible to avoid the reductive tendencies that often hamper analyses of emotions in religious settings, diminishing them into mere inner psychological states, social symbolic systems or neurological scripts. Riis and Woodhead (ibid. I7) criticise the 'deep binaries' that restrain much of the current research on religion and strive to offer an alternative approach that bridges the unproductive dichotomy between reason and emotion, resembling closely the objective of the vernacular religion approach.

Embodiment is also brought forth as a key aspect of the turn within. Embodied religious practices offer patterns, parameters and meanings to connect to in a concrete way in the on-going project of building one's identity and orientating oneself in the physical, social and existential landscape (Weissler 20II: 53). Emotionally engaging and embodied religious experiences resonate with different levels of existential and social life, bringing together unequally personal outlooks with a larger community engaging in shared practice. Boaz Huss notes that many Jews today identify with the embodied, feminine and sensual images found in mystical language, preferring it to the intellectual grand narratives of traditional Judaism (Huss 2007: I I 8). The quest for a religious identification that feels genuine and purposeful is often equated with a search for practices that 'feel real', Chava Weissler claims. As Jews today 'seek meaning through the body' embodiment becomes the 'key to achieving the influx of spirit, which can come through singing, chanting, dancing, and other sorts of ritual movement' (Weissler 201 I: 74).

Emotional engagement is often associated with particular physical and embodied forms and practices in the religious landscape (DeNora 2000: I05). Similarly, research on diverse Jewish liturgies has pointed to the relevance of the affective associations they carry: the musical elements are intimately tied to emotions and emotions, on their part, are central to the human capacity for meaning making (Kaplan 2007: I75; Summit 2000: IO2-4).

\section{The turn to tradition}

In addition to the reflexive turn and the turn within, a third relevant perspective is 
encapsulated in the concept 'turn to tradition' or 'retraditionalisation'. As mentioned above, many Jews today are searching for and developing meaningful practices and ways of relating to their heritage by turning their gaze to history (Kaplan 2007: I73-5). Through music, liturgy and the arts at large emotional links to the past are created that connect the Jewish tradition to a person's living memory (Vincent 20I4: 3 I, I6I). By emphasising the Jewish origin of emerging vernacular rituals, an aura of familiarity is created, Vanessa Ochs argues. Hence, new practices can feel 'genuine' even when tried out for the first time: 'turning to the past evokes certainty, security, and imagined community' (Ochs 2007: 6). Turning to tradition is a valuable resource for those who seek to build a personal religious identity: the perceived link to tradition gives meaning and legitimacy to practices adopted from the past, even if they are significantly altered in the process (Huss 2007: I I 8). Many Jewish communities today seek to legitimise their practice by relating to aspects of the tradition that are generally regarded as 'authentic'. As Stuart Z. Charmé notes, a sense of authenticity has become a significant aspect of the turn to tradition among contemporary Jewry:

As feminist, progressive, gay/lesbian, environmentalist, secular, and many other kinds of Jews lay claim to parts of traditional Judaism that offer recognition and respect to the previously marginalized parts of their identities, they also seek elements that they consider to be 'authentically Jewish'.

(Charmé 2000: I33)

A central question concerns the type of authenticity imagined and sought for. Charmé describes two approaches: essential authenticity, where the true and genuine is sought for in a given normative form of historical
Judaism, as opposed to existential authenticity, which is gauged in relation to the individual self and its ability to give the personal religious engagement depth and meaning. Evidently, Jews of different convictions and outlooks assess authenticity on vastly varying grounds, sometimes resulting in bitter polemics (Charmé 2000: I 50-I). The debates around authenticity are of interest for the current discussion because they often depend on the binary modes of argumentation that the vernacular approach seeks to destabilise. When official religion and everyday religion are defined as mutually exclusive opposites, and the theologically correct is seen to negate or compete with the practically applied, the power to define what is authentic often turns into an emotional and strategic struggle. Yet, from a vernacular point of view it is of no interest to study what practices and traditions in fact are authentic. Rather, the task is to investigate what is seen as authentic and why (Ochs 2007: 28). The aim is not to dismiss all claims of authenticity as confused and unwarranted but rather to discern why the discourse of authenticity is so attractive and affective (Lindholm 2008: $\mathrm{I}_{4} \mathrm{I}-4$ ). Understanding the lure of practices and positions apprehended as authentic is relevant because this lure seems to persist also for persons who take a critically informed and reflexive attitude towards historical knowledge: as a 'motivating force in the modern world' authenticity is as relevant as ever (Lindholm 2013: 390).

For many Jews today, authenticity seems to arise from a feeling of timelessness and familiarity rather than rational reconstruction (Ochs 2007: 29). Thus, looking to history for ways of measuring 'the authentic' can be understood as a nostalgic search for a meaningful and durable identification in a rapidly changing world full of contrasting options. For many people, music seems to offer a tangible arena for negotiating authenticity: 'Music 


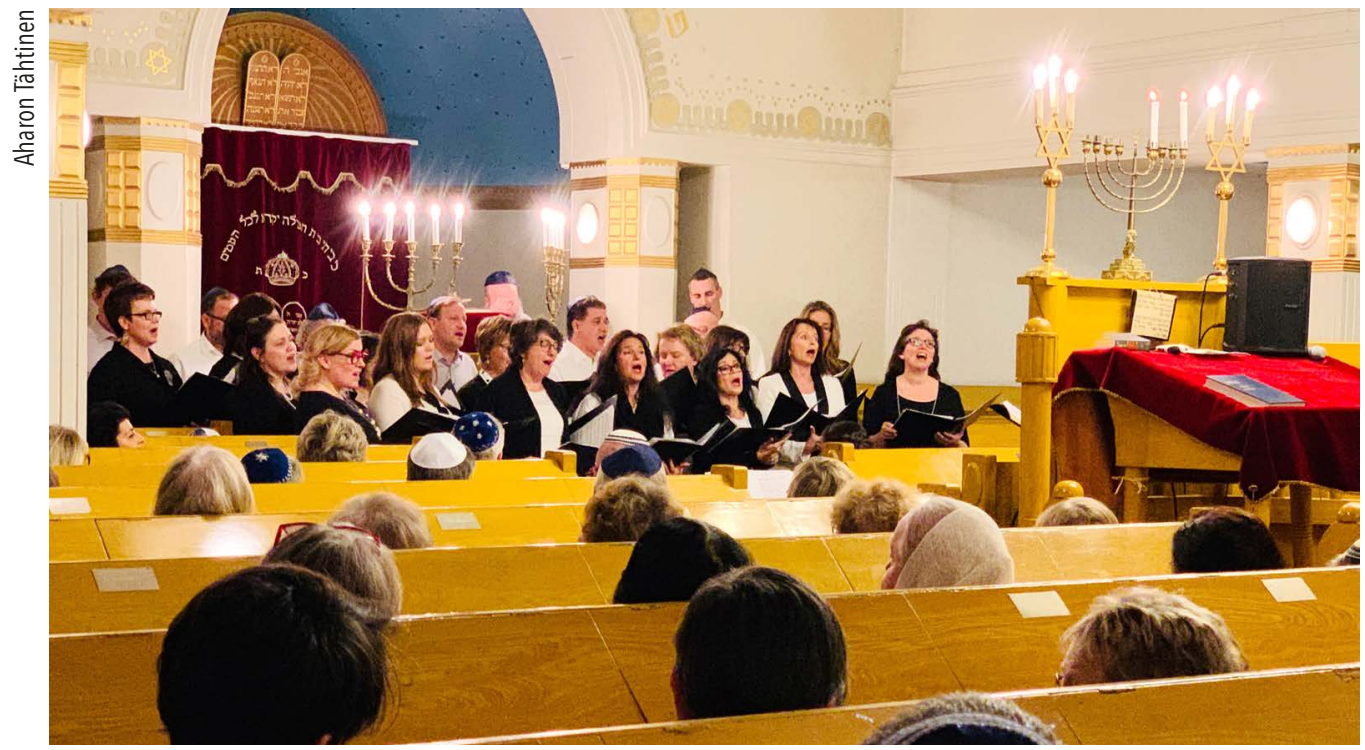

The Hazamir choir performing in the Turku synagogue at Hanukkah 2018. The choir, founded in 1917, is specialised in Jewish music performed in Hebrew and Yiddish.

is and has been at the heart of conflicts and affirmations concerning the essence of being Jewish', Barbara Borts claims (2014: 28). Indeed, many musical practices revitalised or introduced afresh in progressive Jewish communities today have clear ties to traditional, often mystical, practices of the past. However, they are consciously remodelled in relation to the contemporary religious landscape and its requirements, including a liberal, egalitarian and democratic approach, embodied forms of practice and potential for commodification (Cohen 2016: 492-4). Hence, practices that previously were open only to select groups of Jews (based on ethnicity, social class or gender) are today introduced in an inclusive fashion; practices that have fallen into oblivion are rekindled (Ochs 2007: 3 I).

Consequently, the turn to tradition is seldom regarded as a direct re-enactment of past practices, but is more often envisioned in terms of inspiration and rootedness. It reflects a longing to find religiously and culturally significant models from the past and to transform them into highly eclectic forms of practice that can go along with contemporary lives and worldviews. Summit summarises this position as 'tradition gets a vote but not a veto' (2000: I I 2), echoing a phrase minted by Mordecai Kaplan. ${ }^{4}$

In this article, vernacular religion has been presented as perspective that bridges the longstanding dichotomies restraining both the research on and much public debate around religion, such as 'official' and 'popular'. From this vantage point, focus is moved away from such black-and-white assessments and redirected towards the ways in which religiosity is formed and expressed in personal lives, embedded as they are in, and conditioned by, historical and social contexts. Thus, the normative split into authentic or inauthentic religion, sometimes upheld even by researchers in the field, can be surpassed in favour of theoretically and methodologically

4 'We should accept the past as no more authoritative than the present. It should have the right to vote but not the right to veto'(Kaplan I958: 28). 
more nuanced perspectives. By questioning the basic dichotomy between authentic and inauthentic and taking seriously the thoughts and practices of people in their daily lives, the vernacular perspective breaks with established forms of knowledge-creation.

The discussion on authenticity can be taken one step further, however, adding a third alternative to the categories suggested by Charmé. In previous research by the current author (Illman 2018) focusing on progressive European Jewry and the trend of combining liberal theology with increasingly traditional practice, the issue of authenticity came to the fore. The ethnographic analysis showed that a simple division into authentic and inauthentic Jewish practices appeared irrelevant to the informants of the study. They did, however, use the notion hesitantly to describe a shared search for meaning and community rather than a historically essential or purely individual existential striving. Authenticity was thus portrayed as a question of concern, but not in the sense of distinguishing the genuine from the false. Essential authenticity was almost exclusively dismissed. Existential authenticity seemed to catch the images arising from the interviews more poignantly, but also this term fell short in presenting a satisfactory explanation of the strivings to form a practice experienced as true and meaningful in the data.

Therefore, a third dimension to complement Charmé's two-part model of essential and existential authenticity was suggested: expressive authenticity. This term was initially introduced by Charles Lindholm to denote the wish not merely to 'search for depths of the soul hidden beneath surface convention and appearance', but to express this conviction together with others, to live so that you truly 'feel life' (Lindholm 2013: 37 I, 378). This term captures a vernacular perspective on authenticity in a fruitful way: as an effort to find a way to express one's Jewishness that is experienced as historically relevant, liturgically defensible and individually meaningful but also socially cohesive. Expressive

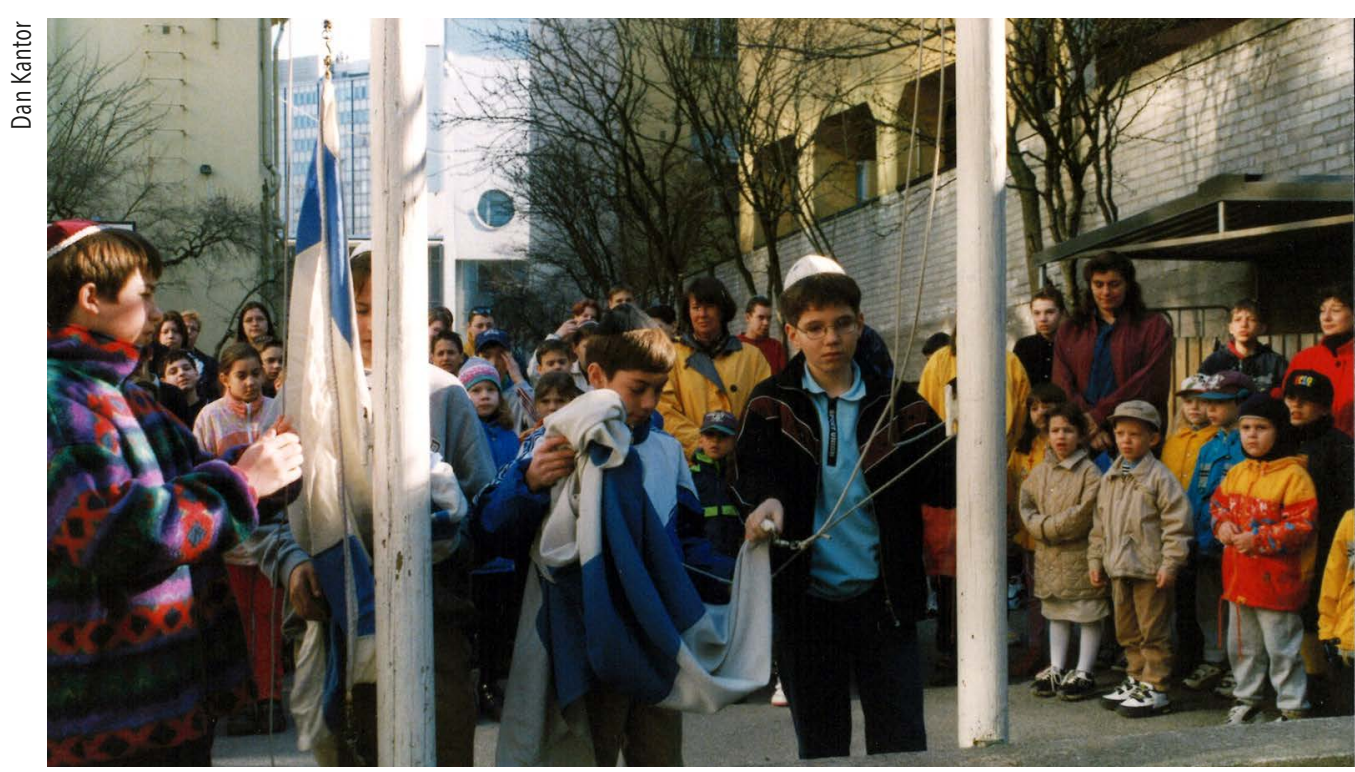

At Yom Ha'atzmaut, the Israeli Independence Day, both the Finnish and the Israeli flags are solemnly raised at the Jewish school in Helsinki. Picture from the 1990s. 
authenticity is a shared practice: it is nurtured by an emotional investment in the religious practices one engages in, but also has a distinct collective and embodied dimension whereby the body becomes a tool for creating meaning. As Weissler has shown, the quest for authenticity among progressive Jews, who turn to tradition in their search for a meaningful and embedded religious practice, is not primarily an intellectual quest, but rather a quest to find religious experiences that 'feel real' (Weissler 20 I I: 74).

To conclude: the broad discussion on vernacular religion, the turns inward and to tradition, as well as the related escalation in interest towards emotional and embodied forms of religious practice can be understood to offer a constructive and deepening perspective on contemporary Judaism. In terms of their epistemological and ontological foundations, the three turns presented above offer a close fit with the vernacular framework, consolidating and clarifying its claims and building a tangible conceptual basis on which ethnographic research can be constructed. The following section of this article will give a concrete example of how this theoretical and methodological approach can be made use of in practice.

\section{Mapping vernacular Judaism in Finland}

As mentioned by way of introduction, a research project entitled 'Boundaries of Jewish Identities in Contemporary Finland' (or simply 'Minhag Finland') has recently been initiated to map vernacular Judaism in Finland, guided by the research framework outlined above. ${ }^{5}$ But how can the small and peripheral Jewish community of Finland offer relevant information illuminating the globally

5 For more information, please see the project website. overarching questions of religion and change within the frames of vernacular Judaism?

We argue that the case of Finland is relevant owing to its exceptional character, which is both unique and representative of general patterns. Finland is one of the few countries with a surviving East European Jewish community post-Holocaust. It is also one of the world's most secularised countries. The Jewish communities of Finland have approximately I 300 members but the number of Jews living in Finland today is estimated at over 2000. Among these, the number of converts and mixed marriages is remarkably high (as much as 95 per cent) but the community remains officially Orthodox and strives to preserve a markedly Finnish-Jewish identity. Thus, the profile of the Jewish community in Finland is quite unique: it is rooted in and still defined as an Orthodox community, but a large part of the membership holds progressive or secular worldviews and distinctly plural religious identifications. The rapidly increasing diversity of Finland is also reflected in the Jewish community, where the blend of cultures, languages and religious views is colourful (Weintraub 2017). However, owing to the small size of the community it is possible to generate a comprehensive understanding of the identity processes at work in it.

\section{Case studies and methodology}

Four dimensions of vernacular Judaism in Finland will be highlighted in the research project: two relating to the broad theme of 'encounters', two to 'customs'. Firstly, the views on interreligious relations in the research data will be monitored. The internal diversity of the Jewish community and its relationship to secularised Finland will also be analysed and related to a Nordic framework. Secondly, encounters taking form through process of intermarriage and conversion will be 
analysed. International research has recently highlighted intermarriage as a key issue for Jewish communities globally (Graham 2016). By locating this topic in the wider context of intra-community relations and relating it to the issue of conversion, these discussions can shed light on significant changes in religious practices and interreligious relations and thereby challenge established assumptions in Jewish studies today (see Czimbalmos in this issue).

Thirdly, the development of vernacular religious customs in Finland will be analysed. Focus is placed on the history and present state of the religious and liturgical customs of the Jewish community in Finland, that is, the so-called Minhag Finland. The aim is to trace the origins and development of the customs, paying attention to historical and societal aspects, such as influences from different regions, ideological and theological movements. Encounters with secular society and interreligious relations play a prominent part also in this strand of the project (see Muir and Tuori in this issue). A final important aspect related to customs, to be surveyed within the project, pertains to foodways. The relevant relationship between food and religion, connecting to tradition as well as adaptation, dynamic innovation and nostalgic preservation, is currently the focus of increasing scholarly attention. The relationship between food and faith is informed by several factors: personal religiosity, emotions and memories as well as social structures, historical lines of development, contexts and ethical standpoints (Harvey 2013). Thus, the project will investigate the background and discussion of vernacular foodways among Finnish Jewry, describe their multi-ethnic culinary traditions and compare them with other Nordic Jewry (see Pataricza in this issue).

To meet the goals of the vernacular approach - to facilitate a dialogue between

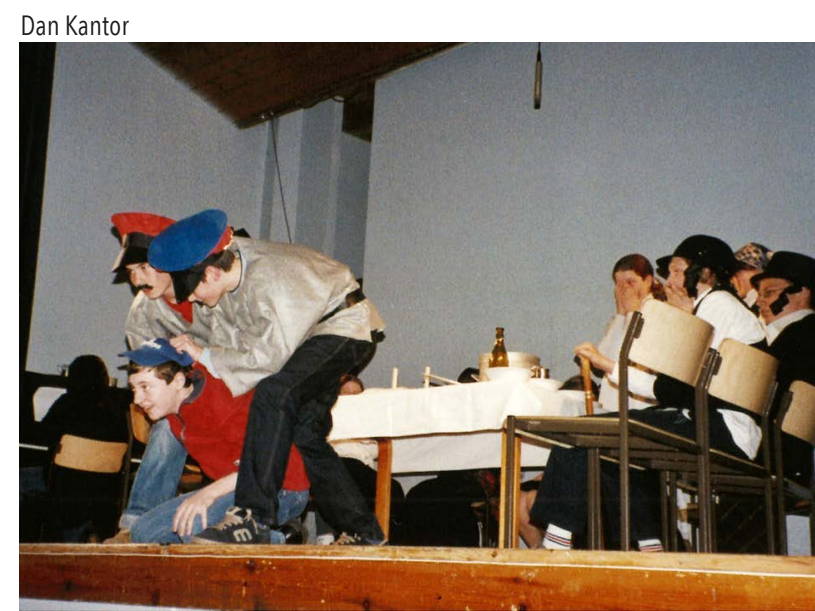

In the autumn of 2003, students at the Jewish school in Helsinki perform the Yiddish-language play Bobe Maises - to great acclaim.

institutional and historical structures and everyday practices, normative regulations and practical adaption, conformity and innovation - the project strives to create a versatile and varied data set. Vernacular religion is never as neatly categorised, unified and structured as it appears in textbook accounts of religious traditions. Rather, it is 'real, particular and often messy' (Gregg and Scholefield 2015: 7). Hence, a corpus of data pertaining to the everyday life of persons who are not religious professionals is optimal. The research material for the current project consists of:

\section{- Historical documents and archival material:} from the National Archives of Finland, the Jewish community and private family archives. The data (including partly unstructured more recent historical data, from the I 970 onwards) is comprehensive and partly unresearched, including valuable information on the everyday life of Jews in Finland, as well as detailed material on community decision-making: minutes of board meetings, documents of religious societies (khevres) from the I 86os onwards. 
- Member registers and legal documents: for example, marriage and birth records (sporadic data from the late I 800 , complete registers starting from I 9 I9).

- Rabbinic letters and correspondence: for example, rabbis' answers to questions regarding religious regulations of diet, family life, moral issues and day-to-day life in Finland in general. In addition, sermons and speeches addressing issues of vernacular religion have been preserved, containing rich parallels to Nordic Jewry.

- Documents pertaining to Jewish everyday life in secular Finland: recipes, guidance for households, interacting with nonJews, observing holidays, bringing up children etc.

- New ethnographic data which is collected in the form of a quantitative questionnaire and in-depth interviews with members of the Jewish community. Data is also generated through methods of participant observation, such as shared cooking.

- Comparative data: archival material and ethnographic data relevant for the comparative analysis is sought through international collaboration with partners in the Nordic countries as well as national partners with expertise on ethnic and interreligious relations in Finland.

An interesting aspect of the archive material, which aids the Nordic comparative analysis, is the fact that most of the large archival materials are written in Swedish and contain Nordic parallels in themselves, for example, decrees from various Nordic communities and cross-references to Nordic siddurim. As mentioned above, new ethnography must be collected in addition to the existing archive data as comparable oral data

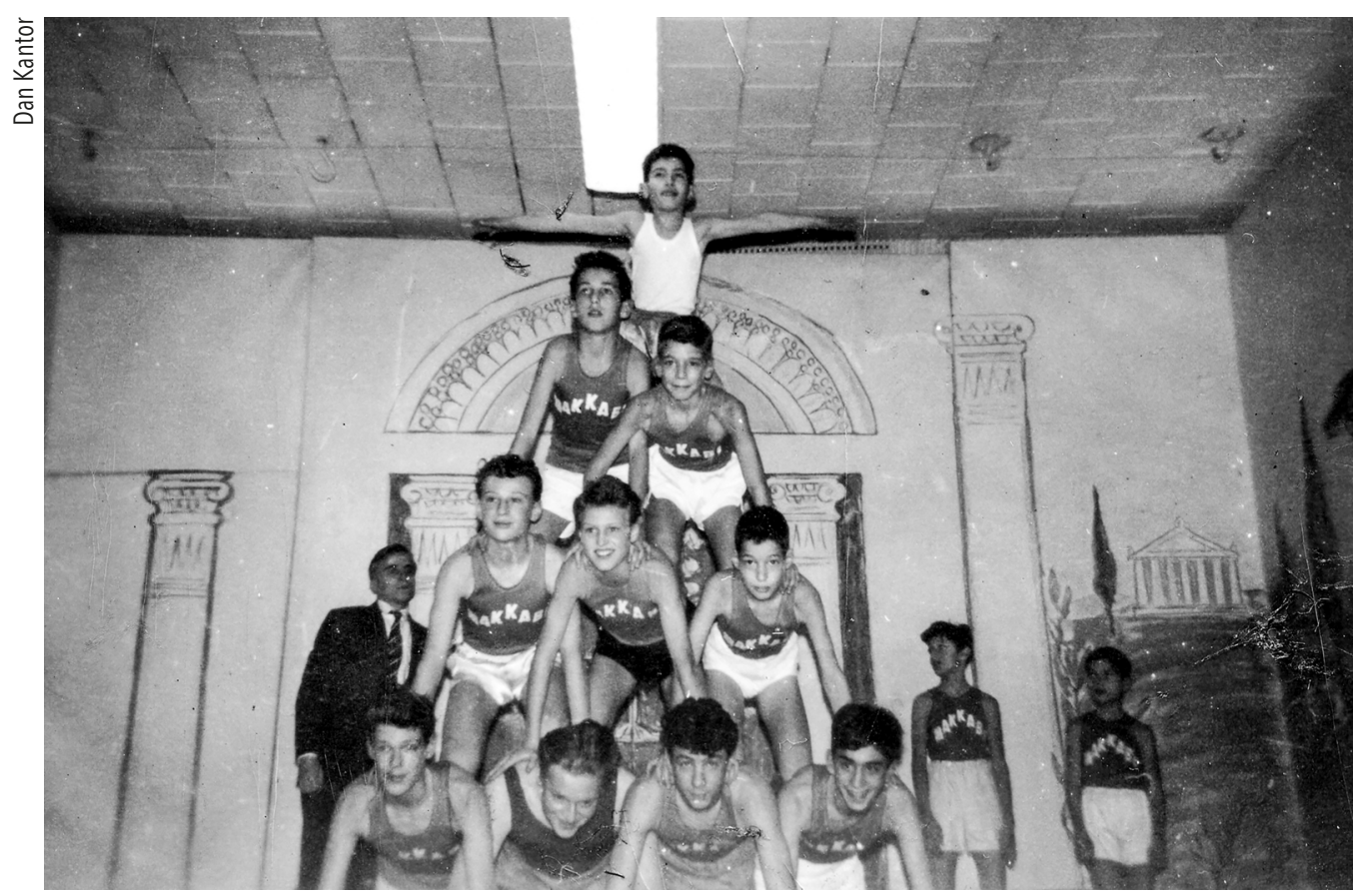

Students from the Jewish school in Helsinki demonstrating their gymnastic skills at the school Hanukkah celebration of 1959. Photo by Dan Kantor. 
and reliable statistic are largely missing in the archives.

Theoretically, the key to success lies in relating the locally embedded, in-depth data to larger contexts of national and international relevance. The core assumption is that the Jews of Finland offer a unique yet representative sample with Nordic Jewry as the most relevant comparative context in view of the intricate mix of similarities and differences in migration history, responses to the Holocaust, social situation and religious customs (Ahlin et al. 20I2; Dencik 20I I; Døving 20r6; Hoffmann 20r6). Through this comparative analysis, the numerically small group of Jews in Finland becomes a specified prism through which the larger context of vernacular Judaism, multicultural identity negotiations and the relevant boundaries these processes face are illuminated.

\section{Conclusion}

Finally, it is time to conclude the discussion outlined in the article, summarising the theoretical and methodological claims and relating them to the ethnographic research project outlined in response to these perspectives. The aim was to present the research perspective of vernacular religion and to assess its ability to offer new insights into and illuminations of the field of Jewish studies. Furthermore, the article has sought to exemplify the theoretical outline by presenting a recently initiated research project applying the framework to the analysis of contemporary Finnish Jewry.

Initially, research pertaining to the field of vernacular religion was described, outlining an approach to the field where religion is understood as a multi-faceted, practical and palpable yet also existential, emotional and experiential aspect of everyday life. The ambition to reach beyond conventional dichotomies and categorisations shaping the research field was stressed, and an integrated perspective - favouring intersectional analyses sensitive both to the overarching sociocultural power structures and to the inner world of experiencing, embodied individuals - was outlined.

The theoretical discussion of religion and change, lying at the core of the vernacular research perspective, was structured around three so-called 'turns' highlighted in recent scholarship. Firstly, it was argued, as a consequence of the increased emphasis on religious self-determination, the reflexive turn emerges, with new ways of positioning oneself within the Jewish landscape, transcending traditional institutional divisions. Secondly, as a feature of the turn within, emotions and embodiment appear as increasingly relevant aspects of religious engagement. Thirdly, elements of practice and ritual experienced as traditionally Jewish are explored and incorporated in various Jewish settings as an aspect of the turn to tradition. In relation to these processes, the notion of bricolage was given special attention as a relevant yet ambiguous aspect of the development. Another concept deemed to be of central relevance was the equally ambiguous notion of authenticity, where a novel category of expressive authenticity was proposed.

The article has also presented a research project designed in response to the vernacular-religion research approach. This study of the everyday practices of Jews in Finland strives to map how theologically unsystematic life-views take form through everyday practices related to institutional religion in the specific, restricted - but representative and relevant - context that is encircled by the ethnography. An important aim is to explore how the informants as individuals and as communities find ways of 'being and doing Jewish' that feel historically and religiously embedded, yet meet their personal needs 
and correspond to the secular, urban lifestyle of their surrounding contexts. The goal was set to relate the locally embedded in-depth data to wider issues of relevance for larger Jewish contexts. In this way, the project was envisioned as a contribution to the theoretical advancement of the research field owing to the relative novelty of vernacular-religion research within Jewish studies and the exceptionality of the Finnish Jewish context.

The study has the potential to bring important stimuli to the Nordic networks within the field. Ethnographically researching the Jews of Finland offers a unique chance to confirm and challenge trends in global Jewry and concerning religion and change on a societal level in general. By investigating very tangibly how traditions and customs are formed today - combining traditional elements from diverse Jewish contexts with secular influx and trends in the Finnish society this project seeks to shed light on issues that have until now been insufficiently addressed. Negotiating boundaries of identity is a process that concerns not only Jews but applies to all ethnic and religious groups, traditional and novel to the Finnish society. Thus, this research will hopefully have a societal impact far beyond the Jewish community, contributing to a greater understanding of the challenges encountered by religious and ethnic minorities and offering tools to increase social justice. On a tangible level, the project will offer new source data for future research on themes relating to the project and improve the conditions for public debate. Hopefully, it will also progress and diversify the study of cross-disciplinary vernacular religion.

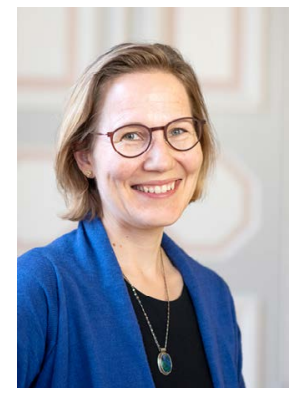

Dr Ruth Illman is Director of the Donner Institute for Research in Religious and Cultural History in Turku/Åbo, Finland, and a docent of comparative religion at Åbo Akademi University and Uppsala University. Her main research interests includes interreligious dialogue, cultural encounters, religion and art and contemporary Judaism.

\section{References}

Ahlin, Lars et al., 201 2. 'Religious diversity and pluralism: empirical data and theoretical reflections from the Danish Pluralism Project', Journal of Contemporary Religion, 27(3), pp. 403-I 8

Altglas, Véronique, 20 14. From Yoga to Kabbalah: Religious Exoticism and the Logics of Bricolage (Oxford University Press)

Ammerman, Nancy T., 2007. Everyday Religion: Observing Modern Religious Lives (Oxford University Press)

Aronson, Janet Krasner, Leonard Saxe, Charles Kadushin, Matthew Boxer, and Matthew A. Brookner, 20r 8. 'A new approach to understanding contemporary Jewish engagement', Contemporary Jewry, online publication, I9.I I.201 8, doi: <https://doi. org/10.1007/si 2397-018-927 I-8>

Bauman, Zygmunt, 2000. Liquid Modernity (Cambridge, Polity Press)

Borts, Barbara, 20 I4. Mouths Filled with Song: British Reform Judaism through the Lens of its Music (Durham University E-Thesis), $<$ http://etheses.dur.ac.uk/Io797/> (accessed 30.3.2019)

Boundaries of Jewish Identities in Contemporary Finland - 'Minhag Finland', Polin-institutet, project website, <http://www.polininstitutet. fi/en/boundaries-of-jewish-identities-incontemporary-finland-minhag-finland/> (accessed 30.3.2019)

Bowman, Marion. 2014. 'Vernacular religion, contemporary spirituality and emergent identities: lessons from Lauri Honko', Approaching Religion, 4(I), pp. Iо I-I 3, doi: <https://doi.org/Io.30664/ar.67542>

Bowman, Marion, and Ülo Valk (eds), $20 \mathrm{I} 2$. Vernacular Religion in Everyday Life: Expressions of Belief (New York, Routledge) 
Charmé, Stuart Z., 2000. 'Varieties of authenticity in contemporary Jewish identity', Jerwish Social Studies, 6(2), pp. I33-55

Cohen, Judah M., 20 r6. 'A holy brother's liberal legacy: Shlomo Carlebach, Reform Judaism, and Hasidic pluralism', American Jewish History, roo(4), pp. 485-509

Dencik, Lars, 20 I r. 'The dialectics of diaspora: on the art of being Jewish in the Swedish modernity', A Road to Nowhere? Jewish Experiences and Uncertainties in the Context of European Unification, ed. Julius Schoeps and Olaf Glöckner (Leiden, Brill), pp. I 2 I-50

DeNora, Tia, 2000. Music in Everyday Life (Cambridge University Press)

Døving, Cora Alexa, 2or6. 'Jews in the news: representations of Judaism and the Jewish minority in the Norwegian contemporary press', Journal of Media and Religion, I 5 (I), I-I 4

Giordan, Giuseppe, and Enzo Pace (eds), 2 or 2. Mapping Religion and Spirituality in a Postsecular World (Leiden, Brill)

Graham, David J., 20 I 2. 'Judaism', Religion and Change in Modern Britain, ed. Linda Woodhead and Rebecca Catto (London, Routledge), pp. 89-99

-2016. Jews in Couples: Marriage, Intermarriage, Cohabitation and Divorce in Britain (London, Institute for Jewish Policy Research

Gregg, Stephen W., and Lynne Scholefield, 2015. Engaging with Living Religion: A Guide to Field-work in the Study of Religion (New York, Routledge)

Gruber, Ruth Ellen, 2002. Virtually Jewish: Reinventing Jewish Culture in Europe (Los Angeles, University of California Press)

Harvey, Graham, 20I 3. Food, Sex and Strangers: Understanding Religion as Everyday Life (Warwick RI, Acumen)

Hoffmann, Christhard, 2016. 'Jewish history as a history of immigration: an overview of current historiography in the Scandinavian countries', Jewish Studies in the Nordic Countries Today, ed. Ruth Illman and Björn Dahla, Scripta Instituti Donneriani Aboensis, 27 (Turku/Åbo, Donner Institute), pp. 203-22 doi: <https://doi.org/10.30674/ scripta.66576>

Hovi, Tuija, 201 4. 'Functions of narrative genres for lived religion', Approaching Religion, 4(I), pp. 8o-8, doi: <https://doi.org/Io.30664/ ar.67540>
Howard, Robert G., 20 I I. Digital Jesus: The Making of a New Christian Fundamentalist Community in the Internet (New York University Press)

Huss, Boaz, 2007. 'The new age of Kabbalah: contemporary Kabbalah, the new age and postmodern spirituality', Journal of Modern Jewish Studies, 6(2), pp. 107-25

Illman, Ruth, 201 7. "'Retaining the tradition but with an open mind': change and choice in Jewish musical practices', Temenos: Nordic Journal of Comparative Religion, 53 (2), pp. 207-29, <https://journal.fi/temenos/article/ view/60982> (accessed 30.3.2018)

2018. Music and Religious Change among Progressive Jews in London: Being Liberal and Doing Traditional (Lanham, Lexington Books)

Kahn-Harris, Keith, and Ben Gidley, 20 ıо. Turbulent Times: The British Jewish Community Today (London, Continuum)

Kaplan, Dana Evan, 2007. 'Reform Judaism', Encyclopaedia Judaica, 2nd edn, ed. Michael Berenbaum and Fred Skolnik (Detroit, Macmillan Reference), pp. I65-83

Kaplan, Mordecai, 1958. Judaism without Supernaturalism: The Only Alternative to Orthodoxy and Secularism (New York, The Reconstructionist Press)

Keysar, Ariela, 20 4 4. 'From Jerusalem to New York: researching Jewish erosion and resilience', Contemporary Jewry, 34(2), pp. I $47^{-62}$

Lindholm, Charles, 2008. Culture and Authenticity (Malden MA, Blackwell Publishing)

2013. 'The rise of expressive authenticity', Anthropological Quarterly, 86(2), pp. 36 I-96

Lundgren, Svante, 2006. 'Jews in Finland', Encyclopedia of the Jewish Diaspora, ed. Avrum Ehrlich (Santa Barbara CA, ABC Clio), pp. I 07 I -6

McGuire, Meredith, 2008. Lived Religion: Faith and Practice in Everyday Life (Oxford University Press)

Merriam-Webster Dictionary, <https://www. merriam-webster.com/dictionary> (accessed I 8.3.2019)

Nynäs, Peter, Ruth Illman, and Tuomas Martikainen, 20 I 5 . 'Rethinking the place of religion in Finland', On the Outskirts of 'the Church': Diversities, Fluidities and New Spaces of Religion in Finland, ed. Peter Nynäs, Ruth Illman and Tuomas Martikainen (Zürich, LIT Verlag), pp. I I -28 
Obadia, Lionel, 20 I 7. 'Comparing "religious diversities"', Approaching Religion, 7(I), pp. 2-9, doi: <https://doi.org/Io.30664/ ar.65900>

Ochs, Vanessa, 2007. Inventing Jewish Ritual (Philadelphia, The Jewish Publication Society)

Partridge, Christopher, 201 4. The Lyre of Orpheus: Popular Music, the Sacred, and the Profane (Oxford University Press)

Pinto, Diana, 2008. 'A new role for Jews in Europe: challenges and responsibilities', Turning the Kaleidoscope: Perspectives on European Jewry, ed. Sandra Lustig and Ian Leveson (New York, Berghahn Books), pp. 27-40

Poveda, Oriol, 20 I 7. According to Whose Will: The Entanglements of Gender and Religion in the Lives of Transgender Jews with an Orthodox Background, Acta Universitatis Upsaliensis, Studies in Religion and Society, I 5 (Uppsala University)

Primiano, Leonard, r 995. 'Vernacular religion and the search for method in religious folklife', Western Folklore, 54(I), pp. 37-56

2012. 'Afterword. Manifestations of the religious vernacular: ambiguity, power and creativity', Vernacular Religion in Everyday Life: Expressions of Belief, ed. Marion Bowman and Ülo Valk (Sheffield, Equinox Publishing), pp. 382-94

Riis, Ole, and Linda Woodhead, 2o г. A Sociology of Religious Emotion (Oxford University Press)

Summit, Jeffrey, 2000. The Lord's Song in a Strange Land: Music and Identity in Contemporary Jerwish Worship (New York, Oxford University Press)

20I6. Singing God's Words: The Performance of Biblical Chant in Contemporary Judaism (New York, Oxford University Press)

Taira, Teemu, 2006. Notkea uskonto (Helsinki, Eetos)

Tweed, Thomas, 201 5. 'After the quotidian turn: interpretative categories and scholarly trajectories in the study of religion since the I 96os', The Journal of Religion, 95(3), pp. 36I85, doi: <https://doi.org/Io.1086/68 I I I 2 >

Vincent, Alana M., 20 I 4. Making Memory: Jewish and Christian Explorations in Monument, Narrative, and Liturgy (Havertown, James Clarke \& Co)

Weintraub, Daniel, 20 I7. 'Juutalaiset ja juutalaisuus Suomessa', Monien uskontojen ja katsomusten Suomi, ed. Ruth Illman, Kimmo Ketola and Jussi Sohlberg (Tampere, Church Research Institute)

Weissler, Chava, 20 I r. 'Performing Kabbalah in the Jewish Renewal movement', Kabbalah and Contemporary Spiritual Revival, ed. Boaz Huss (Ben Gurion University of the Negev Press), pp. 39-74

Wijnia, Lieke, 2or 6. Making Sense through Music: Perceptions of the Sacred at Festival Musica Sacra Maastricht (University of Tilburg)

Wood, Abigail, 201 6. And We're all Brothers: Singing in Yiddish in Contemporary North America (London, Routledge)

Woodhead, Linda, 2016. "The rise of "no religion" in Britain: the emergence of a new cultural majority", Journal of the British Academy, 4, pp. $245^{-6 \text { I }}$ 